\title{
Protection of the Right to Freedom of Religion for Pelajar Kawruh Jiwa
}

\author{
Repulis ${ }^{1}$, Azis Budianto ${ }^{2}$ \\ Borobudur University ${ }^{1,2}$ \\ \{repulisunboro@gmail.com ${ }^{1}$, azis_budianto@borobudur.ac.id ${ }^{2}$ \}
}

\begin{abstract}
The state guarantees freedom of religion for every citizen of Indonesia, as stated in the 1945 Constitution. Restricting religious freedom is an act that violates the basis of the state Pancasila and applicable laws and regulations. It is interesting to observe how it is implemented for Pelajar Kawruh Jiwa? By using a normative approach, accompanied by extracting literature data and field studies, it was found that there were discrimination and prohibition against spiritual students from carrying out their religious activities. The different treatment and rejection from the community signals that the people do not fully understand the guarantee of religious freedom for all Indonesian citizens. The state needs to be present to socialize and guarantee religious freedom for all its citizens so that whatever beliefs they hold can be equal and have the same rights in carrying out their religious activities.
\end{abstract}

Keywords: Religious Freedom Rights; Pelajar Kawruh Jiwa; Indonesian Citizen

\section{Introduction}

Indonesia is known as a religious country. The basis of the Indonesian state, namely the 1945 Constitution and Pancasila, clearly implies that the element of religion is important in the life of the Indonesian people. Religious freedom and guarantees of worship for the people of Indonesia are even stipulated in articles 28 and 29 of the 1945 Constitution. Every Indonesian citizen has the freedom to embrace a religion and has an equal position before the law. In practice, adherents of faiths still experience acts of discrimination. The existence of the paradigm of majority and minority is still valid and makes minorities (believers) unable to freely carry out their worship and beliefs. This problem occurs because many people consider themselves or their group to be superior to others. Personal and group interests are upheld to the point that other parties may be disadvantaged. This research is here to give the reader an idea that there are followers of the faith who also live, live, grow and develop in the Indonesian nation. Adherents of this belief also color diversity in Indonesia. The practice of tolerance is very important in the life of Indonesian society. The state needs to participate in socializing and guaranteeing religious freedom for all its citizens. 


\section{Method}

This study using a qualitative research type with a descriptive analysis method. Through the collection of literature data, researchers collect data from library sources in the form of books, scientific journals, documents, or research results related to the protection of the right to religious freedom for students who are unruly souls. This study emphasizes review, text analysis, and field observations related to predetermined themes. Furthermore, the results of the analysis from the literature data are described following the research formulation/identification, and finally, the results are summarized briefly and straightforwardly.

\section{Result}

\subsection{The right to freedom of religion is not just tolerance for minorities.}

Heterogeneity is a unique fact of Indonesia given the existence of countless ethnic groups, languages, cultures, religions, and natural heritages. In terms of religion, the paradigm of majority and minority appears. The majority refers to the six religions that are constitutionally recognized by the state (Christianity, Catholicism, Islam, Buddhism, Hinduism, Confucianism), while the minority refers to believers. Until now, believers of the faith have not received constitutional recognition from the state but their existence is starting to be seen and taken into account. In realizing a peaceful religious life, a tolerant attitude is needed.

Tolerance is an attitude of mutual respect and respect between groups or between individuals in a diverse society. An attitude of tolerance can minimize the occurrence of discrimination even though there are many different groups or groups in a community group. The term tolerance in religious life can be understood as an attitude of mutual respect and respect among adherents of different religions, including by not forcing others to adhere to a certain religion; not criticizing or insulting other religions for any reason; not prohibiting or disturbing members of other religions from worshiping according to their respective religions and beliefs. Religious tolerance is the tolerance most often echoed, but in its implementation, it still needs to be questioned, given the reality that often occurs in society regarding issues of intolerance and religious radicalism.[1]

In Indonesia, tolerance practice does not represent essential religious freedom for adherents of a belief. They have not had the freedom to show their belief as an identity. For example, the government has not even facilitated administratively the management of KTP with the column for believers. Believers of faith are not allowed to fill in the religion column on the KTP because their belief has not been officially recognized by the Indonesian government. What is needed by believers of the faith is recognition, equal rights, and freedom to worship according to their beliefs. Not to mention the problem of marriage registration, they cannot be facilitated because their beliefs are not included in the community service forum established by the government. In the end, to get the legality of marriage, they must choose one of the six official religions recognized by the government. Therefore, believers of belief appear in two types, namely those of pure belief and those of religious belief. 


\subsection{Kawruh Jiwa Doctrine}

Kawruh Jiwa was born from the teachings of Ki Ageng Suryo Mentaram. Ki Ageng Mentaram Sunlight is a true son of the king of Yogyakarta, prince Hamengkubuwana VII, who was born on May 20, 1892, and died on March 18, 1962. Ki Ageng Suryomentaram names Bendoro aristocratic Raden Mas (BRM) Kudiarmadji and after the age of 18 years named nobility Bendoro Prince Haryo (BPH) Suryomentaram.[2] Starting from BPH Suryomentaram, he had participated in a group of ragong manten to Surakarta and on the way by train saw farmers working in the fields. What he saw touched his heart of how heavy is the burden on the lives of the farmers. Since then, his heart has been restless. Then he often went out of the palace to meditate in places his ancestors used to visit such as Langse Cave, Semin Cave, and Parangtritis.[3] In the end, he decided to leave the palace, go wandering the Kroya area, Purworejo while working odd jobs as a batik trader, farmer, and coolie. He gave up his title of prince and called himself Ki Ageng Suryomentaram.

Ki Ageng Suryomentaram became a teacher of a mystical school called Kawruh Begja or Ilmu Begja which means the science of happiness.[4] Currently, Kawruh Begja is known as Kawruh Jiwa because Ki Ageng Suryamentaram's teachings originate from his search for the soul. One of the most popular moral teachings at that time was Aja Dumeh, which means don't boast, don't puff out your chest, don't belittle others because yourself is more high-ranking, powerful, or wealthy, because humans are essentially the same.

\subsection{Contents of Kawruh Jiwa Teaching}

Ki Ageng Suryomentaram's understanding of humans all starts from his observations of himself. He uses an empirical method that is based on experiments he carried out on himself. By feeling, initiating, and wanting something, marks the movement of life in the human mind. Ki Ageng Suryomentaram tries to reveal the secrets of the human psyche which he sees as the source that determines human behavior in his life. From his analysis, a human image is produced that shows what a human is like rather than whom he is without being separated from the world that surrounds him. Humans always get along with the world around them and are always related to their world. Ki Ageng also shows the basis for human behavior in his world, so that between himself and the world that surrounds him, harmony can be created. He also observes what other people feel. Until finally, he found that the taste of people all over the world is the same, that is, they both need physical and species preservation. It turns out that the taste of human life in this world is the same. The same is the feeling of the troubles, whether heavy or light, even the long or short duration of the ups and downs. What is different is what is liked or hurt. Even though the pen, degree, and sacredness that have been successfully collected are different, the taste of life is the same. This is where the raos langgeng bungah-susah appears.

Overall, Ki Ageng did not pay much attention to the idea of God or systematic thinking about God (theology). This is because Ki Ageng Suryo Mentaram realizes that humans have human limitations in understanding what is behind the reality of everyday life (now and here), not because of a priori rejection of the existence of visible reality. [5] The adherents of this belief are called Pelajar Kawruh Jiwa. The term pelajar/student is used because Ki Ageng Suryamentaram thinks that life is seeking knowledge, understanding oneself, and the existence of the environment. From this, it can be understood that during one's lifetime it is to learn, learn about everything and be in harmony with nature. This fits perfectly with the concept of lifelong learning. 


\subsection{Protection of the Right to Religious Freedom for Students of Kawruh Jiwa}

Article 28E and Article 29 paragraph (1) of the Constitution of the Republic of Indonesia of 1945 has guaranteed the freedom of every citizen to embrace religion and worship under their respective beliefs, accompanied by the obligation of the state to protect every citizen to worship by their respective beliefs, without exception local religion. Therefore, it has become an obligation for the state to protect and guarantee the freedom of its citizens who embrace local beliefs.

A nation cannot develop a new tradition that is completely separate from its historical roots.[6] It is the thought that is rooted in historical roots that inspired the founding people of the Indonesian nation to formulate Pancasila as the basis of national and state life. Apart from that, the position of Pancasila is also a view of the life of the nation. This means Pancasila as a guide and direction for the Indonesian nation in all activities and activities of life and life in all fields.

The Supreme Divine Will is a very important precept for the life of the Indonesian nation. Please God reflects the commitment of the Indonesian nation to build a strong moral foundation and noble character. All Indonesian citizens are free to embrace their respective religions and beliefs by respecting each other's religious rights and trusting each other with full tolerance. In the BPUPKI Conference on June 1, 1945, Sukarno stated: "Indonesia should be a country where every person can worship his God in a free-way. All people should worship God culturally, that is, with no "egoism-religion". And Indonesia should be a Godfearing country."

The embodiment of the values of Pancasila is embodied in the contents of the 1945 Constitution of the Republic of Indonesia (hereinafter referred to as the 1945 Constitution of the Republic of Indonesia. The 1945 Constitution of the Republic of Indonesia has a long history of upholding human rights. attention to human rights (HAM). The 1945 Constitution only talks about universal human rights in two ways, namely the second principle of Pancasila which lays down the principle of "just and civilized humanity" and Article 29 paragraph (2) which guarantees "the independence of each resident has to embrace their religion and worship according to their religion and belief." The rest of the 1945 Constitution only talks about Citizen Rights (HAW / HAM particularistic), or transferred, the HAW is only possible because someone has the status of a citizen of a state. This has become an important legitimation of freedom of religion and adherence to any belief.[7]

With many waves of demands from local beliefs, the government should respond by giving them recognition and protection. This is under Article 28 I paragraph (4) of the 1945 Constitution of the Republic of Indonesia which states that the state, especially the government, is responsible for protecting, advancing, upholding, and fulfilling human rights. Thus, ideally, the government should make policies that consider socio-culture, accommodate all lines and provide legal protection for the constitutional rights of citizens, and strive for the achievement of social justice.

Borrowing religious boundaries put forward by Durkheim that religion is a system of beliefs and practices towards sacred things, namely beliefs and practices that shape the morals of the community of its adherents. The moral of this community shows that religion functions as a social glue or cohesion between one another that integrates humans collectively. In other words, humans are in a passive position that is governed by a moral system that is integrated into the institutional mechanisms of society.[8] 
The amendment to the 1945 Constitution of the Republic of Indonesia caused a shift in the norm structure of the relationship between religion and state which can be seen from 2 aspects, namely freedom, and equality. The aspect of freedom can be viewed from article 28 of the 1945 Constitution of the Republic of Indonesia: Based on extensive interpretations, Article $28 \mathrm{E}$ has provided guarantees to civil religions in Indonesia. Meanwhile, the aspect of equality will be realized if there is no coercion for the adherents of Beliefs that are practiced by the state. In other words, the state should issue regulations protecting civil religions but is not obliged to provide material support. This is different from the official religions recognized by the state, where the state is not only obliged to protect but also have to support it materially.[9]

In addition to the express guarantee in the Constitution, religion also has a significant role in the life of the nation and state. This can be seen in the 2012 vision of Indonesia as stipulated in the MPR Decree Number VII / MPR 2001 regarding the Vision of a Future Indonesia. Article 2 Chapter IV number 1 describes the Vision of Indonesia 2020, among others:[10]

a. The existence of a community of believers, who are pious, virtuous

b. The realization of internal and inter-religious tolerance.

c. The realization of respect for the dignity of humanity.

The Ministry of Religion through the Center for Religious Harmony (PKUB) has created various comprehensive programs and strategies to realize religious harmony, including:

a. Innovation and consolidation of religious harmony programs

b. Striving for the formation of functional staff to guide the harmonization of the people.

c. Multicultural insight development program.

d. Explore various local pearls of wisdom that support harmonization.

e. Establish active partnerships.

f. Empowerment of Religious Harmony Forums.

g. Approaches to the radicals and liberals.

h. Optimization of media.

i. Carry out sharing of real activities that are directly in touch with the interests of the wider community.

j. $\quad$ Service to the Confucians

k. Dialogue.

1. Interfaith Dialogue.

Currently, the concrete steps that need to be taken by the state to protect the freedom of worship for believers in this case as well as for Kawruh Jiwa students are by evaluating and formulating legislation that better guarantees and protects the rights of religion and belief. The evaluation and formation of such legislation must be based on the values of freedom, justice, and equality within the framework of a legal state that upholds the supremacy of law. Thus, the law is not just a tool to create order but to bring prosperity and justice to all people. The teachings practiced by the knowledge of the soul lead to peace not only for its adherents (students of the Kawruh Jiwa) but in practice also have an impact on peace in the community. The teachings of the believers of the faith that bring good impact in Indonesia should be appreciated by the government. The appreciation given is to let the believers live in Indonesia.

\section{Conclusion}

The relationship between religion and state in Indonesia is substantial, meaning that in religion and belief there are substantial teachings and values. This means that in religion or 
belief there are substantive values that contain ethical and moral principles for society and the state. These values serve as references and guidelines in carrying out and implementing public life and state politics. Thus, the state of Indonesia is a country with the One Godhead, with the type of state of the One Godhead according to the basis of just and civilized humanity. To realize justice and civilization, it is necessary to make efforts by the government to be able to maintain and protect the followers of the faith so that they can carry out their worship according to their beliefs. There needs to be socialization from the government to provide understanding and awareness to the adherents of the majority religions so that they can respect and not suppress and even have a negative attitude towards the adherents of the existing beliefs.

\section{Reference}

[1] F. L. K. Putri, "Implementasi Hak Kebebasan Pemeluk Agama Minoritas di Indonesia," Jakarta, 2020.

[2] P. Y. Kecewa, "Ki Ageng Suryomentaram," pp. 1-80, 1892.

[3] R. Suryowiyono, Ki Ageng Suryomentaram Sang Plato Dari Jawa. Yogyakarta: Cemerlang Publishing, 2007.

[4] R. Sugiarto, Psikologi Raos: Saintifikasi Kawruh Jiwa Ki Ageng Suryomentaram. Yogyakarta: Pustaka Ifada, 2015.

[5] A. Afif, Rasio sebagai Pedoman, Rasa sebagai Acuan: Konseptualisasi dan Aktualisasi Filsafat Kawruh Jiwa Ki Ageng Suryomentaram. Yogyakarta: Basabasi, 2019.

[6] A. Wahid, Mengurai Hubungan Agama dan Negara. Jakarta: Gramedia, 1999.

[7] E. Hidayat, "Perlindungan Hak Asasi Manusia Dalam Negara Hukum Indonesia," Asas J. Huk. dan Ekon. Islam, vol. 8, no. 2, pp. 80-87, 2016, [Online]. Available: https://www.neliti.com/publications/56534/perlindungan-hak-asasi-manusia-dalamnegara-hukum-indonesia.

[8] E. Durkheim, The Elementary Forms of Religious Life. London: George Allen \& Unwin Ltd, 1976.

[9] M. Dahlan and A. Liemanto, "Perlindungan Hukum atas Hak Konstitusional Para Penganut Agama-Agama Lokal di Indonesia," J. Area Huk., vol. 10, no. 1, pp. 20-39, 2017.

[10] H. Christianto, "The Significant Impact of Law Number 1 / PNPS / 1965," J. Yudisialudisial, vol. 6, no. 1, pp. 1-16, 2013. 